УДК 615.01

\title{
НЕКОТОРЫЕ ЭКОЛОГО-МЕДИЦИНСКИЕ ПРОБЛЕМЫ СЕВЕРА
}

\author{
Горбачев А. Л. \\ ФГБОУ ВО Северо-Восточный государственный университет, г. Магадан \\ E-mail: gor000@mail.ru
}

\begin{abstract}
На основе литературных и собственных данных дана биогеохимическая характеристика районов Севера. Показана слабая изученность микроэлементного статуса жителей северных регионов. Приведены данные о техногенном загрязнении биосферы северных регионов тяжелыми металлами. Сделан акцент на аккумуляции в биосфере ртути, оказывающей нейротоксичный эффект. На примере ртути и селена показаны антагонистические отношения между химическими элементами в живом организме, следствием чего может быть формирование вторичных микроэлементозов. Причиной отклонения физиологических и биохимических параметров человека в условия современного Севера на фоне загрязнения окружающей среды является нарушение структуры и качества питания. Сделано заключение о том, что для сохранения здоровья мигрантов и коренных жителей необходимо проведение геохимического районирования современных арктических регионов, выявление «предрасположенности» отдельных территорий к биогеохимическим эндемиям, а также проведение профилактических мер защиты населения от эколого-зависимых заболеваний.
\end{abstract}

Ключевые слова: Север, биогеохимия, микроэлементы, питание, здоровье человека.

DOI: $10.34078 / 1814-0998-2020-4-105-113$

На современном этапе развития общества жизненные показатели человека (здоровье, продолжительность жизни, ее качество) становятся все более зависимы от состояния окружающей среды. Связующим звеном между косной природой и биосферой выступают химические элементы, и в этом смысле биохимические и физиологические параметры живых организмов есть производное от геохимического окружения. Считается, что в процессе эволюции именно химические элементы (микроэлементы, биоэлементы) стали основой для формирования всех механизмов регуляции (эндокринных, иммунных, нервных), которые по отношению к системе биоэлементов являются надстройкой (Кожин, Владимирский, 2013).

Со второй половины прошлого века в биосфере отмечается активная эволюция элементного состава, обусловленная антропогенным воздействием на природную среду и усилением миграции химических веществ. Следствием техногенеза биосферы явилось нарушение биогеохимических циклов и формирование искусственных геохимических провинций (Ермаков, 2015). Вы-

(C) Горбачев А. Л., 2020 сокий динамизм социально-экологических процессов, техногенный перенос неорганического вещества, прогрессивное нарастание скорости биосферного обмена химических элементов, социально обусловленная миграция продуктов питания приводят к трансформации элементного профиля человеческих популяций, неспособных динамично адаптироваться к революционным преобразованиям социума и биогеохимической среды.

Отклонения химического состава окружающей среды и соответствующий дисбаланс биоэлементов в живых организмах приводят к нарушению металло-лигандных комплексов, дисфункции регуляторных систем и развитию микроэлементозов - заболеваний биогеохимической природы человека, животных, растений. Микроэлементный гомеостаз подразумевает высокую устойчивость индивидуума к экологическому воздействию. По мнению физиологов, коррекция металло-лигандного комплекса по физиологической значимости сопоставима с коррекцией генетического аппарата (Оберлис и др., 2008).

Проблема природных (эндемических) микроэлементозов значительно усиливается антропо- 
генным фактором. Увеличение содержания химических веществ в биосфере, и в частности в реках и морях, а также ухудшение их санитарномикробиологических показателей происходят настолько стремительно, что это грозит непрогнозируемыми последствиями экологии водных систем и здоровью человека (Трахтенберг, 2018). $\mathrm{C}$ антропогенными микроэлементозами во многих отношениях связывают проблему нарастающего демографического кризиса, а также повышение частоты случаев бесплодных браков среди населения, проживающего в экологически неблагоприятных районах (Оберлис и др., 2008).

В связи с медико-социальной значимостью неорганического компонента биосферы принципиальное значение приобретают знания региональной биогеохимии, распределения химических элементов в окружающей среде и организме человека. Их комплексные показатели являются основой биогеохимического районирования и выделения биогеохимических провинций (Ермаков, 2015). В рамках федеральной программы «Национальная система химической и биологической безопасности Российской Федерации (2000-2014 гг.)» проведено масштабное исследование микроэлементного статуса населения России. Получены сведения о фоновых уровнях химических элементов у жителей различных регионов, опубликовано 5-томное руководство (Элементный..., 2014).

По результатам указанного элементного скрининга наименее изученными оказались северные регионы России. Объяснением слабой биогеохимической изученности Севера явились финансовые, транспортные и методические трудности, связанные с труднодоступными и малонаселенными северными территориями России. Между тем Север представляет собой огромную биогеохимическую провинцию со сниженными адаптивными возможностями человека, где нарушения минерального обмена проявляются на популяционном уровне и требуют медикоэкологического контроля.

Геохимическая среда северных регионов за счет бедных минералами подзолистых почв, слабоминерализованной питьевой воды характеризуется крайне низким содержанием биогенных элементов. Кроме того, в северных регионах слабоминерализованная вода является причиной развития вторичных авитаминозов, что связано с физиологической ролью минеральных веществ в ассимиляции организмом витаминов.

Почвенные и гидрологические условия $\mathrm{Ce}$ вера создают определенные биологические нагрузки для проживающего на этих территориях населения и предопределют риск развития манифестных и скрытых форм микроэлементозов. Природная бедность Севера минералами усили- вается акклиматизационным дефицитом некоторых жизненно важных элементов, прежде всего, железа, кальция и селена (Элементный..., 2014).

Неблагоприятные биогеохимические условия Севера усугубляются загрязнением окружающей среды и аккумуляцией в живых организмах токсических элементов. В научных изданиях последнего времени увеличивается поток информации о глобальном переносе загрязнителей из средних широт в Арктику (Дударев, Одланд, 2017). По мнению исследователей, при рассмотрении географических различий в загрязнении арктических территорий следует учитывать движение воздушных масс и океанических течений, переносящих загрязняющие вещества на огромные расстояния, а также дальность и географию миграционных путей рыбы и морских млекопитающих.

Современная биосфера северных территорий характеризуется повышенным содержанием тяжелых металлов - кадмия, свинца, ртути, «производимых» в полярных регионах и в умеренных широтах Северного полушария. Данные исследований свидетельствуют об усилении загрязнения тяжелыми металлами арктической среды. В частности, выявлено, что содержание $\mathrm{Fe}, \mathrm{Zn}, \mathrm{V}$, $\mathrm{Cu}, \mathrm{Ni}, \mathrm{Mo}, \mathrm{Co}$ в арктических льдах существенно выше, чем в поверхностных водах, в связи с чем таяние ледников может являться значимым источником тяжелых металлов. Показана аккумуляция токсичных элементов в биосфере северных регионов: в растениях (ягель), мясе (оленина, мясо морских млекопитающих), птице, рыбе и морепродуктах (Rigét et al., 2016).

Комплекс тяжелых металлов через пищевые цепи негативно влияет на здоровье населения. Токсичные металлы провоцируют патогенез хронической сердечной недостаточности, нейродегенеративную патологию, воспалительные заболевания кишечника, хронические болезни почек, иммуноаллергические расстройства, а также развивают репродуктивную токсичность и проявляют свойства дисрегуляторов эндокринной системы (Шафран, 2019; Khan et al., 2019).

При сравнении уровней экспозиции к токсическим веществам населения циркумполярной Арктики с соответствующими данными биомониторинга в других регионах планеты становится очевидным, что арктические популяции испытывают более тяжелые нагрузки некоторыми поллютантами, что представляет риск здоровью для проживающих популяций. Например, концентрации ртути в крови резидентов Арктики гораздо выше, чем среди неарктического населения США и Канады (Дударев, Одланд, 2017).

Ртуть является загрязнителем, вызывающим особую озабоченность состоянием арктических экосистем и здоровья человека. По уровню воз- 
действия на живой организм - это один из наиболее токсичных металлов, действующий как кумулятивный яд (Khan et al., 2019). Всемирная организация здравоохранения считает, что ртуть входит в число 10 основных химических веществ, представляющих «серьезную проблему для общественного здравоохранения» (World..., 2013).

Метаанализ данных о содержании ртути в образцах индикаторных организмов среды Севера продемонстрировал отчетливую тенденцию к повышению уровня металла с запада на восток. В последнее время уделяется большое внимание изучению аккумуляции ртути водными экосистемами, в частности отмечено увеличение уровня ртути в арктических озерах. Основным пищевым источником ртути в регионах Севера являются пресноводная и морская рыба, мясо морских млекопитающих и морепродукты, в мышечной ткани которых происходит биоаккумуляция ртути в виде органического соединения метилртути, являющейся сильнодействующим нейротоксином. При сравнительном анализе установлено увеличение содержания ртути и свинца в мясе северных оленей; за последние десятилетия произошло существенное повышение ртути и селена в печени полярных медведей Канады, Аляски и Гренландии (селен в избытке оказывает токсический эффект) (Pilsner et al., 2010).

В рыбе, отловленной на территории Чукотки, обнаружено высокое содержание ртути и свинца. Получены данные о превышении допустимых значений ртути в горбуше, выловленной в реках континентальной Чукотки - источниках питьевой воды для местных жителей (Куценогий и др., 2010).

Загрязнение биосферы ртутью и ее аккумуляция в живых организмах - это масштабный микроэлементоз, характерный не только для Севера. В волосах сицилийских рыбаков выявлена высокая концентрация ртути, значительно превышающая показатели контрольной группы, что, по мнению исследователей, указывает на опасность ртутной интоксикации рыбаков из-за высокого потребления загрязненной рыбы (Giangrosso et al., 2016).

Но основные данные о загрязнении ртутью касаются жителей именно арктических регионов. При обследовании инуитов, проживающих в Канаде (арктический Квебек), у женщин детородного возраста и в крови беременных выявлена высокая частота избытка свинца и ртути, связанная с употреблением в пищу местной рыбы и морепродуктов, что может приводить к нарушениям развития нервной системы потомства (Dallaire et al., 2003).

Среди беременных женщин, проживающих в Гренландии, концентрация ртути и кадмия в кро- ви также была взаимосвязана с потреблением морепродуктов. Показано, что ртуть представляет серьезную опасность для фертильности и исхода беременности, так как может вызывать нарушения репродуктивной функции (Bjorklund et al., 2019).

У 96\% аборигенов Ханты-Мансийского автономного округа (континентальный регион) уровень ртути был повышен в 4 раза и коррелировал с высоким содержанием этого элемента в пресноводной рыбе (Корчина, 2008).

Современные исследования жителей Магаданской области и Чукотки показали наличие ртути и свинца у коренного населения приморских поселков, основу питания которых составляет рыба. Концентрация ртути не превышала безопасно допустимого уровня, но была выше фоновых показателей по РФ (Горбачев, 2016).

При анализе токсичных элементов в организме человека следует учитывать проявления сложных конкурентно-антагонистических отношений между биоэлементами, следствием чего может быть вытеснение эссенциальных элементов токсичными с формированием вторичных гипоэлементозов. Физиологическими антагонистами ртути выступают селен и сера. Селен, как мощный антиоксидант и иммуномодулирующий элемент, является функциональным антидотом ртути, которая, в свою очередь, при избыточных концентрациях вытесняет селен из биологических сред.

Сильная положительная связь между концентрациями ртути и селена в тканях многих видов рыбоядных диких животных, особенно хищных морских млекопитающих, хорошо документирована. Взаимосвязь ртуть - селен представляет собой взаимодействие системы токсикант - нутриент, которое имеет отношение как к базовой биологии, так и к оценке риска для окружающей среды. Млекопитающие и птицы с высоким трофическим уровнем могут быть частично защищены от токсичной метилртути вследствие хелатирования неорганической ртути селеном в молярном соотношении $1: 1$. Эти отношения ртути и селена в мышцах, печени и почках исследованы для большого числа видов морских животных Гренландии. При этом показано, что у большинства исследованных особей молярные концентрации селена преобладали над содержанием в тканях ртути (Dietz et al., 2018).

Дальнейшая техногенная аккумуляция ртути в Мировом океане не может быть нейтрализована элементами-антагонистами, что представляет потенциальную угрозу общественному здоровью. Повышенное содержание ртути у аборигенов Чукотки (чукчи, эскимосы) отмечено еще в 70-х гг. прошлого века (Зорина, Бацевич, 2011). Причем его избыточное содержание уже в то 
время соответствовало районам геохимических аномалий. Но высокие показатели ртути были сбалансированы и высоким содержанием селена. Избыточные концентрации обоих элементов объяснимы особенностями диеты аборигенных жителей - употреблением мяса морских животных (кит, морж, тюлень), как богатого селеном, так и аккумулирующего метилртуть. За прошедшее время произошли глобальные природносоциальные изменения (экология, климат, питание и др.), что требует пересмотра физиологического статуса аборигенов, включая и параметры минерального обмена.

Ранее нами было показано, что у приезжих жителей по мере проживания на Севере отмечается снижение уровня некоторых эссенциальных элементов - железа, кальция и селена, что можно рассматривать как функциональное истощение их резервов и формирование акклиматизационного дефицита (Горбачев и др., 2007). Но аналогичная ситуация характерна и для современной популяции аборигенных жителей (эвены, коряки, чукчи), у которых отмечено пониженное содержание большой группы эссенциальных элементов (кобальт, магний, хром, йод), включая и селен (Горбачев, Луговая, 2015).

В регионах Севера аккумуляция в организме жителей нейротоксичной ртути с одновременным дефицитом эссенциального селена может быть основой малоизученных микроэлементозов. Кроме участия в развитии неврологических заболеваний, существуют данные, что повышенный уровень ртути провоцирует развитие сахарного диабета и гипертонии, также обсуждается роль ртути в развитии аутизма (Горбачев, Луговая, 2019).

Биогеохимическая ситуация северных территорий, пригодная для коренных жителей, может оказаться дискомфортной и даже экстремальной для приезжего населения. Адаптивные перестройки мигрантов в условиях Севера сопровождаются напряжением обменных процессов, формированием акклиматизационного дефицита элементов и, в конечном счете, нарушением элементного гомеостаза, что усугубляет природную недостаточность жизненно важных элементов. Кроме этого, миграционная активность населения и несоответствие физиологии приезжих жителей среде обитания, в том числе и региональной биогеохимии, ведут к срыву адаптации и могут быть основой различных болезней многофакторной природы (Кучер, 2017), включая и комплексные микроэлементозы.

Природные условия Севера (особенно арктических территорий) с большой долей условности можно назвать естественной средой проживания человека. В плане комфорта - это агрессивная среда, где человек подвержен жесткому воздей- ствию комплекса природно-климатических факторов. Это экстремальный температурный и ветреный режимы, повышенные энергетические траты, контрастный ритм фотопериодичности, резкие перепады атмосферного давления, гипоксия, аномалии геомагнитных полей, пустынность и однообразие ландшафта и др. Комплекс природно-климатических факторов Севера формирует глобальный медико-биологический феномен - синдром полярного напряжения (Казначеев, 1980), приводящий к нарушению обменных процессов и развитию краевых форм патологии.

В то же время Север представляет собой своеобразную природную лабораторию, пригодную для исследования адаптивных реакций человека. Проживание человеческих популяций в экстремальных условиях длительное историческое время (аборигенное население), равно как и наличие на Севере приезжего населения - мигрантов из комфортных природно-климатических регионов, проявление при этом адаптивных и дезадаптивных реакций, являются идеальной натурной базой для исследования вопросов экологической физиологии, включая изучение резервных возможностей человека в условиях Арктики. Ocoбый интерес представляют еще существующие «изоляты» - аборигенные сообщества, проживающие в отдаленных местах Севера и сохранившие этнические традиции, обычаи и быт. Изолированные сообщества аборигенов являются уникальной моделью для изучения адаптивных возможностей человека в экстремальных условиях (климат, биогеохимия, питание).

Считается, что действие североспецифических факторов практически не компенсируется социальными или другими мерами защиты. Но современные возможности цивилизации (функциональная одежда, адекватное обмену веществ питание) способны частично нивелировать экстремальное воздействие Севера. Но не все средовые факторы могут быть ослаблены, нейтрализованы или компенсированы «благами» цивилизации. К неизменным, постоянно действующим природным факторам Севера, кроме сезонной светопериодики, геомагнитных аномалий и перепадов атмосферного давления, следует отнести геохимические особенности арктических регионов - слабоминерализованную питьевую воду и бедные минералами местные продукты питания, что предопределяет физиологический дефицит эссенциальных микронутриентов. Кроме того, природная нехватка микроэлементов у приезжих жителей Севера усугубляется их акклиматизационным дефицитом (железо, селен, кальций), а также несбалансированной структурой рационов питания как мигрантов, так и коренного населения. Причем главную роль в обеспечении обменных и адаптивных процессов в условиях Севера 
играет именно питание (Истомин и др., 2018; Никифорова и др., 2018).

Считается, что аборигенное население Севера максимально адаптировано к природноклиматической среде, включая и биогеохимическое окружение. Однако уход арктических народов от традиционного питания сопровождается повышением риска дефицита эссенциальных микронутриентов, в том числе железа, цинка, меди, марганца, селена и ряда других элементов (Kuhnlein et al., 2004; Боринская и др., 2009; Кучер, 2017; Малярчук, 2018). Это свидетельствует о биологической ценности традиционного питания и необходимости его сохранения для обеспечения потребностей аборигенного населения.

В то же время, несмотря на то что традиционная пища аборигенов является важнейшим источником макро- и микронутриентов, в ней отмечается повышенный уровень тяжелых металлов, хлорорганических соединений, а также радионуклидов. В частности, среди эскимосов и чукчей Чукотки повышен риск алиментарного воздействия токсичных металлов. Так, среди всех случаев загрязнения образцов пищи в российской Арктике, Сибири и на Дальнем Востоке загрязнение ртутью, свинцом, мышьяком и кадмием распределено примерно в равных пропорциях (Дударев, Одланд, 2017).

Питание играет ключевую роль в обеспечении обменных и адаптивных реакций. Известно, что для аборигенов Севера с традиционным укладом жизни характерен особый обмен веществ - «полярный метаболический тип» с доминированием в диете белково-липидных компонентов и минимумом углеводов (Казначеев и др., 1980). Такой тип метаболизма способствует адаптации к экстремальным условиям среды, обладает антистрессорным эффектом, предотвращает развитие сердечно-сосудистых и других заболеваний, связанных с нарушением обменных процессов (Cевостьянова, 2013; Малярчук, 2018).

Несмотря на изначальное преобладание в рационе коренных жителей Севера белковожировой пищи, распространенность артериальной гипертензии и метаболического синдрома среди аборигенов Севера (Чукотка, Эвенкия, Северная Канада, Гренландия) оказалась парадоксально ниже относительно обитателей средних широт (Кривощеков, Охотников, 2000). Этот феномен связывают с поступлением в организм ненасыщенных жирных кислот омега-3 (рыба, мясо морских животных), оказывающих антисклеротическое и кардиопротекторное действие. В то же время питание северных народов в силу природно-экологического окружения может быть не сбалансировано по минеральному составу.

Исследователи считают, что эволюционно выработанные механизмы обмена веществ являют- ся генетически закрепленными (Боринская и др., 2009; Кучер, 2017). Однако революционные изменения природно-социальной среды (экология, питание, образ жизни) способны нарушить наследственные механизмы обмена. Разрушение традиционного уклада жизни аборигенного населения Севера изменило их рацион питания (Козлов и др., 2008). Переход на европейскую кухню (смешанное питание, избыток углеводов) привел к срыву адаптивных процессов и развитию метаболических заболеваний, связанных с интенсификацией углеводного обмена и повышением в крови атерогенных липидов (Севостьянова, 2013; Малярчук, 2018).

Физиологическая зависимость от липиднобелкового питания и недостаточное содержание в нем адаптогенных компонентов, включая минеральные вещества, при смешанном питании приводят к дополнительному снижению биологической устойчивости организма человека.

Исследования липидного обмена у аборигенного населения Чукотки выявили повышение в крови жителей прибрежной зоны в сравнении с тундровыми районами общего холестерина и липопротеинов низкой плотности (Куценогий и др., 2010). При этом у аборигенов отмечены авитаминозы и появление нехарактерных ранее болезней, в частности рахита (Богословская и др., 2007). Эпидемиологические исследования эскимосов Аляски выявили распространенность у них заболеваний атеросклеротической этиологии (Greenberg et al., 2009).

Возникновение метаболической патологии у аборигенных жителей Севера может быть также связано с загрязнением окружающей среды, нарушениями биогеохимических циклов и изменением уровня и соотношений биоэлементов в организме аборигенов.

При планировании микроэлементного скрининга в арктических регионах уже априори можно прогнозировать микроэлементозы, вызванные дефицитом железа, йода, кальция, магния и избытком ртути. Возможные эндемии природного или техногенного генеза могут быть связаны как с нарушением баланса отдельных элементов, так и с негативным воздействием на человека их непредсказуемых комбинаций.

Одной из значимых эколого-медицинских проблем жителей Севера является дефицит солей кальция и магния, что связано с преимущественным употреблением населением поверхностных вод, отличающихся слабой минерализацией и пониженной жесткостью (Горбачев и др., 2007; Луговая, Степанова, 2016). Дефицит и дисбаланс этих элементов способствуют формированию заболеваний сердечно-сосудистой системы, в том числе гипертонической болезни. В регионах с мягкой водой уровень заболеваемости 
гипертонической болезнью на 25-30\% выше по сравнению с другими регионами. Ведущее значение в патогенезе артериальной гипертензии придается магнию: именно его дефицит рассматривается в качестве первичного звена (Кириллова и др., 2006).

Особое внимание при исследовании биогеохимии арктических территорий следует уделить йоду. Йодный дефицит по-прежнему остается актуальной и острой медико-социальной проблемой, которая не решена даже в странах, где достаточно отработаны и внедрены методы индивидуальной и коллективной профилактики йоддефицитных заболеваний (Рекомендации..., 2018).

Изменение структуры питания и снижение в рационе рыбы и морепродуктов у жителей арктических регионов привели к возникновению у них йоддефицитных заболеваний. В условиях йодного дефицита биосферы и отсутствия должной йодной профилактики у населения арктических регионов можно прогнозировать наличие тяжелых форм йодного дефицита (нарушение физического и ментального развития, снижение популяционного уровня IQ, патология щитовидной железы, иммунодефицитные состояния, нарушение репродуктивной функции, раннее старение).

Причем йодный дефицит характерен для всего российского севера, включая европейские, сибирские и азиатские северные территории, в том числе Магаданскую область и Чукотский автономный округ. Как отмечено ранее, территория Магаданской области и особенно ее континентальные районы соответствуют очагам зобной эндемии. В Чукотском автономном округе уровень заболеваний щитовидной железы, связанных с йодной недостаточностью (нетоксический зоб, субклинический гипотиреоз, эндемический зоб) у детей, подростков и взрослого населения в 1.5 раза и более превышал среднероссийские показатели (Материалы..., 2017).

Медицинской статистики по заболеваниям биогеохимической природы нет. Но, аналогично появлению метаболических нарушений у представителей современной популяции Севера, у жителей неисследованных арктических регионов можно ожидать проявление неотмеченных ранее нарушений минерального обмена.

Насущная потребность в освоении северных территорий, изучении и разработке арктического шельфа, разведке и добыче полезных ископаемых, защите границ усилит приток на Север людей из других регионов России (воинская служба, вахтовый метод, длительное проживание). Учитывая глобальные изменения экологической среды, социально-миграционная активность диктует необходимость ревизии геохимическо- го районирования современных арктических регионов (вода, почва, продукты питания), выявления «предрасположенности» отдельных территорий к биогеохимическим эндемиям и проведения профилактических мер защиты населения от экологически зависимых заболеваний.

\section{ЛИТЕРАТУРА}

Богословская Л. С., Слугин И. В., Загребин И. А., Крупник И. И. Основы морского зверобойного промысла : науч.-метод. пособие. Москва - Анадырь : Институт Наследия, 2007. 480 с.

Боринская С. А., Козлов А. И., Янковский Н. К. Гены и традиции питания // Этнографическое обозрение. 2009. № 33. С. 117-137.

Горбачев A. Л. Ртуть как приоритетный загрязнитель окружающей среды // Микроэлементы в медицине. 2016. Т. 17. Вып. 2. С. 3-9.

Горбачев А. Л., Луговая Е. А. Особенности элементного статуса детей с расстройством аутистического спектра // Микроэлементы в медицине. 2019. 20. № 3. C. 20-30.

Горбачев А. Л., Луговая Е. А. Элементный профиль организма аборигенных жителей Северо-Востока России // Вестник Северо-Восточного научного центра ДВО РАН. 2015. № 1. С. 86-94.

Горбачев А. Л., Добродеева Л. К., Теддер Ю. Р., Шацова Е. Н. Биогеохимическая характеристика северных регионов. Микроэлементный статус населения Архангельской области и прогноз развития эндемических заболеваний // Экология человека. 2007. № 1. C. 4-11.

Дударев А. А., Одланд Й. О. Здоровье человека в связи с загрязнением Арктики - результаты и перспективы международных исследований под эгидой АМАП // Экология человека. 2017. № 9. С. 3-14.

Ермаков В. В. Геохимическая экология и биогеохимические критерии оценки экологического состояния таксонов биосферы // Геохимия. 2015. № 3. C. 203-221.

Зорина Д. Ю., Бацевич В. А. Микроэлементный статус коренного населения Арктики (чукчи, эскимосы) по результатам анализа волос // Вестник Московского университета. Сер. 23. Антропология. 2011. № 4. C. 105-111.

Истомин А. В., Федина И. Н., Шкурихина С. В., Кутакова Н. С. Питание и Север: гигиенические проблемы арктической зоны России (Обзор литературы) // Гигиена и санитария. 2018. Т. 97, № 6. C. 557-563. https://doi.org/10.18821/0016-9900-201897-6-557-563

Казначеев В. П. Современные аспекты адаптации. Новосибирск : Наука, 1980. 190 с.

Казначеев В. П., Панин Л. Е., Коваленко Л. А. Актуальные проблемы рационального питания пришлого населения Заполярья и аборигенов Севера // Вопросы питания. 1980. № 1. С. 23-27.

Кириллова А. В., Доршакова Н. В., Дуданов И. П. К вопросу о патогенезе гипертонической болезни и ишемической болезни сердца при дефиците кальция и магния в условиях Севера // Экология человека. 2006. № 1. С. 3-8. 
Кожин А. А., Владимирский Б. М. Микроэлементозы в патологии человека экологической этиологии. Обзор литературы // Экология человека. 2013. № 9. C. $56-64$.

Козлов А. И., Нувано В., Здор Э. Диета Чукотки // Химия и жизнь. 2008. № 4. С. 42-45.

Корчина Т. Я. Взаимосвязь концентрации ртути, свинца и кадмия в волосах коренных жителей ХантыМансийского автономного округа и их содержание в местных продуктах питания // Вестник РУДН. Сер. Экология и безопасность жизнедеятельности. 2008. № 4. С. 62-69.

Кривощееков С. Г., Охотников С. В. Производственные миграции и здоровье человека на Севере. Новосибирск : СО РАМН, 2000. 117 с.

Куценогий К. П., Савченко Т. И., Чанкина О. В., Журавская Э. Я., Гырголькау Л. А. Элементный состав крови и волос коренных жителей Севера России с разной биогеохимической средой обитания // Химия в интересах устойчивого развития. 2010. Т. 18, № 1. C. 51-61.

Кучер A. H. Ген-средовые взаимодействия как основа формирования здоровья // Экологическая генетика. 2017. Т. 15, № 4. С. 19-32.

Луговая Е. А., Степанова Е. М. Особенности питьевой воды Магадана и здоровья населения // Гигиена и санитария. 2016. 95 (3). С. 241-246.

Малярчук Б.А. Долговременные ген-средовые взаимодействия и генетика нарушений метаболизма в популяциях коренного населения Северо-Востока Азии // Экологическая генетика. 2018. Т. 16, № 2. C. 30-35. Doi: 10.17816/ecogen16230-35

Материаль государственного доклада «О состоянии санитарно-эпидемиологического благополучия населения в Чукотском автономном округе в 2016 году». Анадырь, 2017. 127 с.

Никифорова Н. А., Карапетян Т. А., Доршакова H. B. Особенности питания жителей Севера (Обзор литературы) // Экология человека. 2018. № 11. С. 20 25.

Оберлис Д., Харланд Б., Скальный А. Биологическая роль макро- и микроэлементов у человека и животных. Санкт-Петербург : Наука, 2008. 544 с.

Рекомендации по мониторингу программ йодирования соли и оценке статуса йодной обеспеченности населения // Клиническая и экспериментальная тиреоидология. 2018. Т. 14, № 2. С. 100-112. Doi: $10.14341 /$ ket9734

Севостьянова E. В. Особенности липидного и углеводного метаболизма человека на Севере (литературный обзор) // Бюллетень сибирской медицины. 2013. T. 12, № 1. C. 93-100.

Трахтенберг И. М. Проблема микроэлементов: прошлое и настоящее (приоритетные медицинские аспекты) // Актуальные вопросы современной микроэлементологии, г. Киев, 2018. С. 7-9.
Шафран Л. М. Медицинская элементология: новое направление, новая парадигма // Микроэлементы в медицине. 2019. Вып. 20. № 4. С. 63-68.

Элементный статус населения России. Ч. 5. Элементный статус населения Сибирского и Дальневосточного федеральных округов / Л. И. Афтанас и др.; под ред. А. В. Скального, М. Ф. Киселева. СанктПетербург : Медкнига «ЭЛБИ-СПб», 2014. 544 с.

Bjorklund G., Chirumbolo S., Dadar M., Aaseth J. Mercury exposure and its effects on fertility and pregnancy outcome // Basic \& Clinical Pharmacology. Toxicology. 2019. 125 (4). 317-327.

Dallaire F., Dewailly E., Muckle G., Ayotte, P. Time trends of persistent organic pollutants and heavy metals in umbilical cord blood of Inuit infants born in Nunavik (Quebec, Canada) between 1994 and 2001 // Environmental Health Perspectives. 2003. 111. 1660-1664.

Dietz R., Mosbech A., Flora J., Eulaers I. Interactions of climate, socio-economics, and global mercury pollution in the North Water // Ambio. 2018. 47 (2). 281-295.

Giangrosso G., Cammilleri C., Macaluso A., Vella A., D’Orazio N., Graci S., Lo Dico G. M., Galvano F., Giangrosso M., Ferrantelli $V$. Hair Mercury Levels Detectionin Fishermen from Sicily (Italy) by ICP-MS Method after Microwave-Assisted Digestion // Bioinorganic Chemistry and Applications. 2016. (3, article 82). 1-5.

Greenberg C. R., Dilling L. A., Thompson G. R., Seargeant L. E., Haworth J. C., Phillips S., Chan A., Vallance H. D., Waters P. J., Sinclair G., Lillquist Y., Wanders R. J., Olpin S. E. The paradox of the carnitine palmitoyltransferase type 1a P479L variant in Canadian Aboriginal populations // Molecular Genetic and Metabolism, 2009. 96. 201-207.

Khan F., Momtaz S., Abdollahi M. The relationship between mercury exposure and epigenetic alterations regarding human health, risk assessment and diagnostic strategies // Journal of Trace Elements in Medicine and Biology 2019. 14. 52. 37-47.

Kuhnlein H. V., Receveur O., Soueida R., Egeland G. M. Arctic indigenous peoples experience the nutrition transition with changing dietary patterns and obesity // Journal of Nutrition. 2004. 134 (6). 1447-1453.

Pilsner J. R., Lazarus A. L., Nam D. H., Letcher R. J., Sonne C., Dietz R., Basu N. Mercury-associated DNA hypomethylation in polar bear brains via the luminometric methylation assay: A sensitive method to study epigenetics in wildlife // Molecular Ecology. 2010. 19 (2). 307-314.

Rigét F., Vorkamp K., Bossi R., Sonne C., Letcher R. $J$., Dietz $R$. Twenty years of monitoring of persistent organic pollutants in Greenland biota: A review // Environmental Pollution. 2016. 217. 114-123.

World Health Organization [Internet]. Mercury and health (Fact sheet No. 361). Geneva: WHO; 2013. Available from: http://www.who.int/mediacentre/factsheets/ fs361/en/ [accessed 11 October 2013]. 


\title{
SOME ECOLOGICAL AND MEDICAL PROBLEMS OF THE NORTH
}

\author{
A. L. Gorbachev
}

\author{
North-Eastern State University, Magadan
}

\begin{abstract}
Based on the literature and our own data, a biogeochemical characteristic of the regions of the North is given. The poor knowledge of the microelement status of the inhabitants in the northern areas is shown. Data on technogenic pollution of the North's biosphere by heavy metals are presented. Emphasis is placed on the accumulation in the biosphere of mercury, whith its a neurotoxic effect. Exemplified by mercury and selenium, the antagonistic relationships between chemical elements in a living organism are shown, which may result in the formation of secondary microelements. The reason for the violation of the human physiological and biochemical parameters in the current North conditions against the background of environmental pollution is a violation of the nutrition structure and quality of. It is concluded that, in order to preserve the health of migrants and indigenous people, it is necessary to conduct geochemical zoning of modern Arctic regions, to identify the "predisposition" of certain territories to biogeochemical endemicity, as well as to take preventive measures for protecting the population against environmentally dependent diseases.
\end{abstract}

Keywords: North, biogeochemistry, trace elements, nutrition, human health.

\section{REFERENCES}

Bjorklund, G., Chirumbolo, S., Dadar, M., Aaseth, J., 2019. Mercury Exposure and its Effects on Fertility and Pregnancy Outcome, Basic \& Clinical Pharmacology. Toxicology. 125 (4), 317-327.

Bogoslovskaya, L. S., Slugin, I. V., Zagrebin, I. A., Krupnik, I. I., 2007. Fundamentals of Sea-Hunting Industry: Scientific and Methodological Manual. Moscow - Anadyr, Institute of Heritage [In Russian].

Borinskaya, S. A., Kozlov, A. I., Yankovsky, N. K., 2009. Genes and Food Traditions, Ethnograficheskoe Obozrenie. 33, 117-137 [In Russian].

Dallaire, F., Dewailly, E., Muckle, G., Ayotte, P., 2003. Time Trends of Persistent Organic Pollutants and Heavy Metals in Umbilical Cord Blood of Inuit Infants Born in Nunavik (Quebec, Canada) between 1994 and 2001, Environmental Health Perspectives. 111, 1660-1664.

Dietz, R., Mosbech, A., Flora, J., Eulaers, I., 2018. Interactions of Climate, Socio-Economics, and Global Mercury Pollution in the North Water, Ambio. 47 (2), 281-295.

Dudarev, A. A., Odland, J. O., 2017. Human Health in Connection with the Pollution of the Arctic - the Results and Prospects of International Research under the Auspices of AMAP, Human Ecology. 9, 3-14 [In Russian].

Elemental Status of the Population of Russia. Part 5. Elemental Status of the Population of the Siberian and Far Eastern Federal Districts, L. I. Aftanas, et al., Eds. of A.V. Skalnoy, M. F. Kiseleva, 2014. St. Petersburg, ELBI-SPb [In Russian].

Giangrosso, G., Cammilleri, C., Macaluso, A., Vella, A., D’Orazio, N., Graci, S., Lo, Dico, G. M., Galvano, F., Giangrosso, M., Ferrantelli, V., 2016. Hair Mercury Levels Detectionin Fishermen from Sicily (Italy) by ICP-MS Method after Microwave-Assisted Digestion, Bioinorganic Chemistry and Applications. (3, Article 82), 1-5.

Gorbachev, A. L., 2016. Mercury as a Priority Environmental Pollutant, Trace Elements in Medicine. 17, 2, 3-9 [In Russian].
Gorbachev, A. L., Lugovaya, E. A., 2015. The Elemental Profile of the Organism of the Indigenous Inhabitants of the North-East of Russia, Vestnik NESC FEB RAS. 1, 8694 [In Russian].

Gorbachev, A. L., Lugovaya, E. A., 2019. Features of the Elemental Status of Children with Autism Spectrum Disorder, Trace Elements in Medicine. 20, 3, 20-30 [In Russian].

Gorbachev, A. L., Dobrodeeva, L. K., Tedder, Yu. R., Shatsova, E. N., 2007. Biogeochemical Characteristics of the Northern Regions. Microelement Status of the Population of the Arkhangelsk Region and the Prognosis of the Development of Endemic Diseases, Human Ecology. 1, 4-11 [In Russian].

Greenberg, C. R., Dilling, L. A., Thompson, G. R., Seargeant, L. E., Haworth, J. C., Phillips, S., Chan, A., Vallance, H. D., Waters, P. J., Sinclair, G., Lillquist, Y., Wanders, R. J., Olpin, S. E., 2009. The Paradox of the Carnitine Palmitoyltransferase Type 1a P479L Variant in Canadian Aboriginal Populations, Molecular Genetics and Metabolism. 96, 201-207.

Istomin, A. V., Fedina, I. N., Shkurikhina, S. V., Kutakova N. S., 2018. Nutrition and the North: Hygiene Problems in the Arctic Zone of Russia (Literature Review), Hygiene and Sanitation. 97, 6, 557-563. https: //doi.org/10.18821/0016-9900-2018-97-6-557-563 [In Russian].

Kaznacheev, V.P., 1980. Modern Aspects of Adaptation. Novosibirsk, Nauka [In Russian].

Kaznacheev, V. P., Panin, L. E., Kovalenko, L. A., 1980. Actual Problems of Rational Nutrition of the Alien Population of the Arctic and Aboriginal People of the North, Nutrition Issues. 1, 23-27 [In Russian].

Khan, F., Momtaz, S., Abdollahi, M., 2019. The Relationship between Mercury Exposure and Epigenetic Alterations Regarding Human Health, Risk Assessment and Diagnostic Strategies, Journal of Trace Elements in Medicine and Biology. 14, 52, 37-47. 
Kirillova, A. V., Dorshakova, N. V., Dudanov, I. P. 2006. On the Issue of Pathogenesis of Hypertension and Coronary Heart Disease with Calcium and Magnesium Deficiency in the North, Human Ecology. 1, 3-8 [In Russian].

Korchina, T. Ya., 2008. The Relationship between the Concentration of Mercury, Lead, and Cadmium in the Hair of the Indigenous Inhabitants of the Khanty-Mansiysk Autonomous Okrug and Their Content in Local Food Products, RUDN, Journal of Ecology and Life Safety. 4, 62-69 [In Russian].

Kozhin, A. A., Vladimirsky, B. M., 2013. Microelementoses in Human Pathology of Ecological Etiology. Literature Review, Human Ecology. 9, 56-64 [In Russian].

Kozlov, A. I., Nuvano, V., Zdor, E., 2008. Diet of Chukotka, Chemistry and Life. 4, 42-45 [In Russian]. Krivoshchokov, S. G., Ohotnikov, S. V., 2000. Industrial Migrations and Human Health in the North. Novosibirsk, SO RAMN [In Russian].

Kucher A. N., 2017. Gene-Environmental Interactions as the Basis for the Formation of Health, Ecological Genetics. 15, 4, 19-32 [In Russian].

Kuhnlein, H. V., Receveur, O., Soueida, R., Egeland, G. M., 2004. Arctic Indigenous Peoples Experience the Nutrition Transition with Changing Dietary Patterns and Obesity, The Journal of Nutrition. 134 (6), 1447-1453.

Kutsenogy, K. P., Savchenko, T. I., Chankina, O. V., Zhuravskaya, Ya., Gyrgolkau, L. A., 2010. Elemental Composition of Blood and Hair of the Indigenous People of Russia's North with Different Biogeochemical Habitats, Chemistry for Sustainable Development. 18, 1, 51-61 [In Russian].

Lugovaya, E. A., Stepanova, E. M., 2016. Features of Drinking Water in Magadan and Public Health, Hygiene and Sanitation. 95 (3), 241-246 [In Russian].

Malyarchuk, B. A., 2018. Long-Term GeneEnvironment Interactions and Genetics of Metabolic Disorders in Aboriginal Populations of Northeast Asia, Ecological Genetics. 16 (2), 30-35. doi: 10.17816/ ecogen16230-35 [In Russian].

Materials of the State Report "On the State of the Sanitary-Epidemiological Well-Being of the Population in the Chukotka Autonomous Region in 2016: Anadyr, 2017 [In Russian].
Nikiforova, N. A., Karapetyan, T. A., Dorshakova, N. V., 2018. Features of Nutrition of the Inhabitants of the North (Literature Review), Human Ecology. 11, 20-25 [In Russian].

Oberlis, D., Harland, B., Skalny, A., 2008. Biological Role of Macro- and Microelements in Humans and Animals. St. Petersburg, Nauka [In Russian].

Pilsner, J. R., Lazarus, A. L., Nam, D. H., Letcher, R. J., Sonne, C., Dietz, R., Basu, N., 2010. Mercury-Associated DNA Hypomethylation in Polar Bear Brains via the Luminometric Methylation Assay: A Sensitive Method to Study Epigenetics in Wildlife, Molecular Ecology. 19 (2), 307-314.

Recommendations on Monitoring Salt Iodization Programs and Assessing the Status of Iodine Provision for the Population, 2018. Clinical and Experimental Thyroidology. 14, 2, 100-112. doi: 10.14341/ket9734 [In Russian].

Rigét, F., Vorkamp, K., Bossi, R., Sonne, C., Letcher, $R$. J., Dietz, R. 2016. Twenty Years of Monitoring of Persistent Organic Pollutants in Greenland Biota: A Review, Environmental Pollution. 217, 114-123.

Saffran, L. M., 2019. Medical Elementology: a New Direction, a New Paradigm, Trace Elements in Medicine. 20, 4, 63-68 [In Russian].

Sevostyanova, E. V., 2013. Features of Human Lipid and Carbohydrate Metabolism in the North (Literature Review), Bulletin of Siberian Medicine. 12, 1, 93-100 [In Russian].

Trakhtenberg, I. M., 2018. The Problem of Microelements: Past and Present (Priority Medical Aspects), Actual Problems of Modern Microelementology. Kiev. 7-9 [In Russian].

World Health Organization [Internet]. Mercury and Pealth (Fact Sheet No. 361). Geneva: WHO; 2013. Available from: http://www.who.int/mediacentre/ factsheets/fs361/en/ [accessed 11 October 2013].

Yermakov, V. V., 2015. Geochemical Ecology and Biogeochemical Criteria for Assessing the Ecological State of Biosphere Taxa, Geochemistry. 3, 203-221 [In Russian].

Zorina, D. Yu., Batsevich, V. A., 2011. Microelement Status of the Indigenous Population of the Arctic (Chukchi, Eskimos) Based on Hair Analysis, MSU Vestnik. Ser. XXIII. Anthropology. 4, 105-111 [In Russian]. 